\title{
A POTÊNCIA DAS IMAGENS NA OBRA DE ROBERTO ALVIM: DIAGRAMAÇÃO, DRAMATURGIA E ENCENAÇÃO
}

Felipe Cordeiro*

RESUMO: Partindo de estudos acerca das sobrevivências das imagens no teatro e na literatura, este trabalho coteja três aspectos da obra de Roberto Alvim: diagramação, dramaturgia encenação; propondo, assim, um panorama pelo viés imagético de sua produção. A abordagem metodológica espećífica dessas três instâncias se justifica pela relação intrínseca existente entr elas e pelo fato de que seu processo de criação e organização definirá, posteriormente, a forma de visibilidade do objeto artístico produzido.

PALAVRAS-CHAVE: Roberto Alvim; imagem; diagramação; dramaturgia; teatro. *2felipecordeiro@gmail.com

Mestrando em Estudos Literários da FALE/UFMG. Realiza pesquisa de aperfeiçoamento cientifico em Recepção Clássica na Faculdade de Letras da Universidade de Coimbra. É bacharel em Interpretação
Teatral pela EBA/UFMG.

RESUMEN: Partiendo de estudios acerca de las sobrevivencias de imágenes en el teatro y literatura, este trabajo coteja tres aspectos de la obra de Roberto Alvim: diagramación, dramaturgia y puesta en escena; proponiendo, así, un panorama por el sesgo de las imágenes de su producción. El abordaje metodológico specífico denes de su producción. El abordaje metodoćgico trínseca entre ellas existente y por el hecho de que su proyecto de creación y organización definirá, posteriormente, la forma de visibilidad del objeto artístico producido.

PALABRAS-CLAVE: Roberto Alvim; imagen; diagramación; dramaturgia; teatro. 
1. BARTHES. Mitologias, p. 111.

2. BARTHES. Mitologias, p. 110 .
No fundo, considero a época contemporânea um interregno para o poeta, que a ela não deve se misturar: ela está por demais caduca e em efervescência preparatória para que ele tenha outra coisa a fazer senão trabalhar en mistério, com vistos a

A poesia é um edifício estranho ao resto do mundo.

Mallarmé

\section{TODO PENSAMENTO EMITE UM LANCE DE DADOS}

Roland Barthes em seu livro Mitologias, no capítulo Dois mitos do jovem teatro, assinala:

O nosso teatro repousa sobre a dura lei da troca; é necessário e suficiente que os serviços do encenador sejam visíveis e que cada espectador possa controlar o rendimento do seu ingresso; resultado: uma arte dirigida ao mais urgente, que se manifesta, sobretudo, como uma série descontínua logo computável - de êxitos formais. ${ }^{1}$

$\mathrm{O}$ autor segue argumentando que existem duas grandes heranças infelizes do teatro burguês: a combustão do ator e o achado. A primeira diz respeito a exigência do "sacrifício" que o público espera do artista, seus humores, lágrimas e transpiração; ou seja, ele se entrega ao demônio do teatro é devorado pelo seu personagem, "como medida da paixão que lhe compramos", ${ }^{2}$ e, assim, é digno de piedade e admiração. A outra equivale à garantia do "estilo", a procura pela "novidade a todo custo", 3 que encerraria o espectador na servidão do puro formalismo.

Ora, segundo escreveu Perrone-Moysés, "quando disseram a Mallarmé que ele não chorava em seus versos, o poeta respondeu: 'Também não me assoo neles". ${ }^{4}$ Abordando o poema Um lance de dados, experiência clássica no que diz respeito a tipografia, diagramação e versos não-lineares, a autora comenta que uma obra como esta "dá trabalho ao leitor e não lhe oferece nenhum prêmio imediato, de prazer narcísico ou de informação prática. E é sobretudo essa falta de compensação, mais do que a dificuldade de leitura, que cria a resistência dos leitores". ${ }^{5}$

Invocamos Mallarmé nesse preâmbulo e uma breve consideração barthesiana sobre o teatro, pois nosso objetivo neste texto é o de cotejar a relação entre a imagem e a escrita, porém tendo como objeto de análise textos dramáticos e espetaculares. ${ }^{6}$ É importante ressaltar que, no campo canônico dos estudos teatrais, um tema como este pode ser considerado uma afronta às investigações que ainda possuem como norte as clássicas teorias de Patrice Pavis. Conforme observa Rojo:

Parece uma proposta ousada unir conceitos próprios da esté tica, ligada à filosofia, e de práticas de produção teatral, pois aparentemente pertencem a mundos diferentes. Porém, a
3. BARTHES. Mitologias, p. 110

PERRONE-MOYSÉS. Inútil poesia outros ensaios breves, p. 30.

5. PERRONE-MOYSÉS. Inútil poesia outros ensaios breves, p. 30.

6. O texto dramático diz respeito ao texto escrito "publicado ou publicável, [...] texto legível, ou pelo menos audivel, sob uma cenica" (PAVIS Análise dos cenicá (PAVIS. Anállsé dos espeláculos, p. A3). Já o tex texto dramático em relaza com dra nático em relaçáo da os deño da encenaçăo (texto verbal, gestual, cenográfico, musical MARINIS Comprender MARINIS. Comprender el teatro. Lineamentos de una nueva teatrología, p. 23).
EM TESE
BELO HORIZONTE
v. 22
N. 3
SET.-DEZ. 2016
CORDEIRO. A potência das imagens na obra de Roberto Alvim [...]
. 232-244

Crítica Literária, outras Artes e Mídias 
7. ROJO. Teatro latino-americano em diálogo: produção e visibilidade, p. 29 .

8. RAJEWSKY. Intermidialidade, intertextualidade e "remediação": uma perspectiva literária sobre a intermidialidade, p. 25.

9. O autor, a quem agradecemos, gentilmente, cedeu algumas de suas obras ainda não publicadas para a elaboração deste texto. questão estética, entendida como uma forma de pensar a arte, está ligada à possibilidade de refletir sobre a existência ou não de um tipo de utopia, ou melhor, de heterotopia, dentro do objeto artístico a ser pensado, e isso muda de acordo com os contextos históricos específicos. Por outro lado, a história e a arte sofrem uma tensão produzida pela ruptura de fronteiras definidas. ${ }^{7}$

Por se tratar de um estudo pautado em "referências intermidiáticas", ${ }^{8}$ elencamos a produção artística e intelectual de Roberto Alvim ${ }^{9}$ como propulsora de nossos questionamentos. Interessa-nos discutir três aspectos de sua obra: diagramação, dramaturgia e encenação; propondo, portanto, um panorama pelo viés imagético de sua criação.

Nos últimos anos, o diretor, dramaturgo e teórico tem acumulado, em parceria com sua companhia Club Noir, os prêmios mais importantes do teatro nacional (Shell, APCA, BRAVO!, Questão de Crítica, dentre outros), passou a lecionar em diversas instituições, tanto brasileiras quanto internacionais, e foi o primeiro autor do país publicado numa das mais importantes coleções de dramaturgia contemporânea europeia, a Les Solitaires Intempestifs, em 2005.

Em seu livro Dramáticas do transumano e outros escritos seguidos de Pinokio (2012), o autor articula apontamentos em torno do conceito dramáticas do transumano, que tem como finalidade pensar o teatro como alteridade radical, problematizando, desse modo, uma ideia hegemônica acerca do que seja o sujeito e apontando a dramaturgia como alternativa de reinvenção do homem. Segundo Alvim, o teatro é "o lugar de experienciarmos o tempo, o espaço e a condição humana de outros modos, para além da vivência que a cultura nos proporciona". ${ }^{10}$ É interessante mencionar aqui que esta obra foge aos padrões clássicos de diagramação de livros. Há todo um cuidado com o preenchimento do espaço das páginas: são usadas distintas tipografias, que variam em tamanho, cor e forma, de acordo com o que tais imagens dão a ver; existe o que poderíamos chamar de uma iconologia do intervalo (Warburg) entre uma frase e outra, uma vez que sua obra é "uma espécie de gigantesco condensador recolhendo todas as correntes energéticas que tinham animado e animavam ainda a memória [...], tomando corpo em suas "fantasias". ${ }^{11}$ Alvim revisita a história do teatro ocidental e cria seu próprio palimpsesto, atento à visibilidade da linguagem a ao gesto de sua escrita.

Compor uma página é um gesto. A página é um palco onde as palavras rodopiam, interpelam-se, respondem-se, repetem-se, retomam-se, repelem-se ou se equilibram. [...] As frases fluem de página em página; os parágrafos se dilatam ou se precipitam. E eis os títulos e os espaços em branco, sem falar nos frontispícios, cul-de-lampe ${ }^{12}$ ou capitulares. Compor uma
10. ALVIM. Dramáticas do transumano e outros escritos seguidos de Pinokio, p. 13.

11. AGAMBEN. Aby Warburg e a ciência sem nome, p. 137.

12. O cul-de-lampe é, de acordo com o Dicionário Aurélio da Língua Portuguesa, "a vinheta no fim de um capítulo, em um livro". (N.T.)

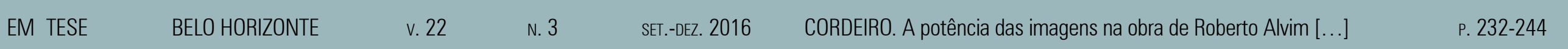


14. ROJO. Teatro latino-americano em diálogo: produção e visibilidade.

13. BUTOR. Sobre a escrita e a arte, $\mathrm{p}$. 41-43, grifos nossos. história é um gesto. [...] Pensar é um gesto. Folheamos um volume. Passamos a outro. Uma imagem serve de indício que faz partir em busca de uma referência antiga, americana, científica... Depois de tantas revoluções, peregrinações, explorações, investigações, reencontramo-nos às margens de seu teatro ou de sua página, e fazemos o gesto escritural com seus dedos e todo o seu corpo, ou todos os seus corpos. ${ }^{13}$

A abordagem metodológica específica dessas três instâncias (diagramação, dramaturgia e encenação) se justifica pela relação intrínseca existente entre elas e pelo fato de que seu

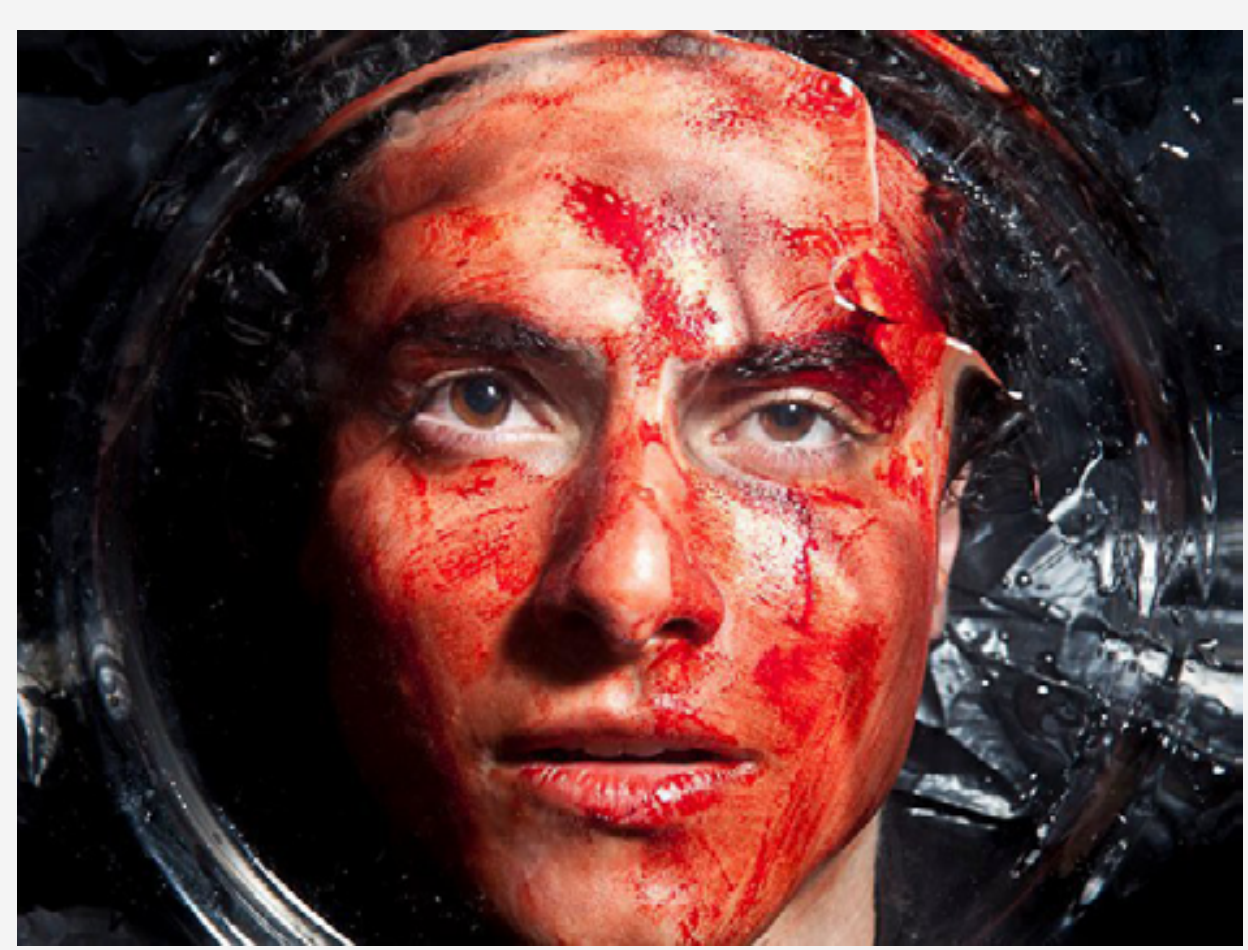

processo de criação e organização definirá, posteriormente, a forma de visibilidade do objeto produzido. ${ }^{14}$ Em Alvim, a encenação requer um texto prévio. Este, por sua vez, só existe graças a materialidade do objeto escrito. Por fim, toda essa relação culmina na cena teatral - que posteriormente será objeto de conceitualização teórica. Cria-se, desta forma este perpetuum mobile, no qual cada uma dessas classes perpetua a existência da outra.

\section{A CRIAÇÃO}

Segundo Alvim, "é muito difícil atacar a imagem dentro da imagem. O ponto é atacar a linguagem, não existe sujeito, é só linguagem. [...] Existe a linguagem e o corpo que é a letra. A letra é anterior à linguagem e tem a ver com o mistério da encarnação". ${ }^{15}$ Nessa colocação, podemos perceber um dos principais operadores de Alvim: a linguagem. É a partir da experimentação de arquiteturas linguísticas que diferem do padrão hegemônico que o artista problematiza a ideia de sujeito presente no teatro ocidental desde os longínquos tempos de Shakespeare.

Sabemos que a primazia do texto e das escrituras está introjetada de maneira muito forte em nossas sociedades. Um exemplo disso é o fato de que as três grandes religiões monoteístas, conforme nos atenta Butor, ${ }^{16}$ se fundamentam cada uma a partir de um livro: a Torá, a Bíblia e o Alcorão.

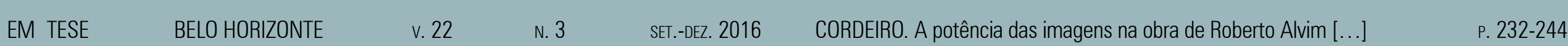

15. Entrevista concedida ao site Horizonte da Cena. Disponível em com/a-ambicao-da-originalidade entrevista-com-roberto-alvim-2/>. Acesso em: 30 jun. 2016.

6. BUTOR. Sobre a escrita e a arte p. 19 
17. BUTOR. Sobre a escrita e a arte, p. 23

18. BUTOR. Sobre a escrita e a arte p. 23

19. CHRISTIN. A imagem enformada pela escrita, p. 64
O livro seria, dessa forma, "uma celebração da palavra revelada", ${ }^{17}$ que serviria para iluminá-la, apenas tornando mais visível a luz da qual ele é a fonte.

Anteriormente a todo mundo visível, há a palavra divina. "No princípio era o verbo" (o logus, a palavra): assim começa o Evangelho de São João. No Gênesis, Deus “diz”, e então podemos "ver" os astros, as plantas, os animais e, por fim, o homem e os homens. A imagem desenvolve as sementes, resume um longo discurso, preenche um silêncio. ${ }^{18}$

Partindo de um outro discurso, Anne-Marie Christin argumenta que

A escrita não constitui uma representação da fala; ela nasceu de uma estrutura elaborada a partir da imagem, na qual a fala integrou os elementos de seu sistema que eram compatíveis com ela. A tese da "representação" repousa sobre dois postulados que visam negar à imagem - numa civilização onde, como sabemos, a linguagem é considerada como único vetor legítimo do pensamento - seu papel decisivo nas origens da invenção da escrita. ${ }^{19}$

Para Jean-Luc Nancy, a oposição entre imagem e texto é apenas mais uma forma cristalizada de dicotomia. Imagem e texto deveriam ser vistos da mesma forma que a alma e o corpo: "cada um é o limite do outro, seu horizonte de interpretação”. ${ }^{20}$

Diante dessas colocações, mais uma vez enxergamos como é essencialmente híbrida a relação entre verbo, escrita, livro, pintura, imagem, linguagem etc. Por isso nossa necessidade em pincelar, mesmo que brevemente, cada uma dessas fronteiras, a fim de melhor situar a obra de Alvim e todos os desdobramentos e provocações que ela suscita.

Aspiramos aqui argumentar o caráter discutível de críticas teatrais que abordam determinadas peças a partir de um aferido caráter 'pictural', assinalando que uma cena $\mathrm{X}$ se "parece com um quadro". Para dar suporte a esta hipótese, buscamos as palavras de Liliane Louvel, em suas indagações acerca dos entrecruzamentos da literatura com a pintura, quando destaca:

Observemos desde já que uma possível fonte de erro seria procurar diferentes maneiras de manifestação do pictural fora do texto. Do nosso ponto de vista, estas só teriam valor de ilustração. [...] Os critérios sobre os quais repousaria a analogia seriam subjetivos e não textuais; eles dependeriam da cultura do leitor crítico e a aproximação seria aleatória. ${ }^{21}$

No espetáculo Genesis (2015), Alvim trabalha com a origem do universo e da criação, como o próprio nome, etimologicamente, já indica.
20. NANCY apud SEDLMAYER. Devolver ao uso comum: sobre a profanação da imagem em Giorgio Agamben e Lars Von Trier, p. 237.
EM TESE
BELO HORIZONTE
v. 22
N. 3
SET.-DEZ. 2016
CORDEIRO. A potência das imagens na obra de Roberto Alvim [...]
P. 232-244

Crítica Literária, outras Artes e Mídias 
A imagem da Figura 2 nitidamente nos remete a uma pintura: suas cores, dimensionalidades e jogos de luz. No caso desta obra de Alvim, desde sua literatura até a posterior encenação, toda uma estratégia de significação está em jogo, sendo relevante para a imagem total de Genesis, conforme podemos conferir no texto dramático da peça:

A própria materialidade da dramaturgia de Alvim, sua diagramação, já indicam o que virá a ser seu material cênico. A didascália aponta a configuração espacial das personagens em cena, a forma como as palavras estão dispostas na página agirão diretamente no ritmo da fala dos atores, as

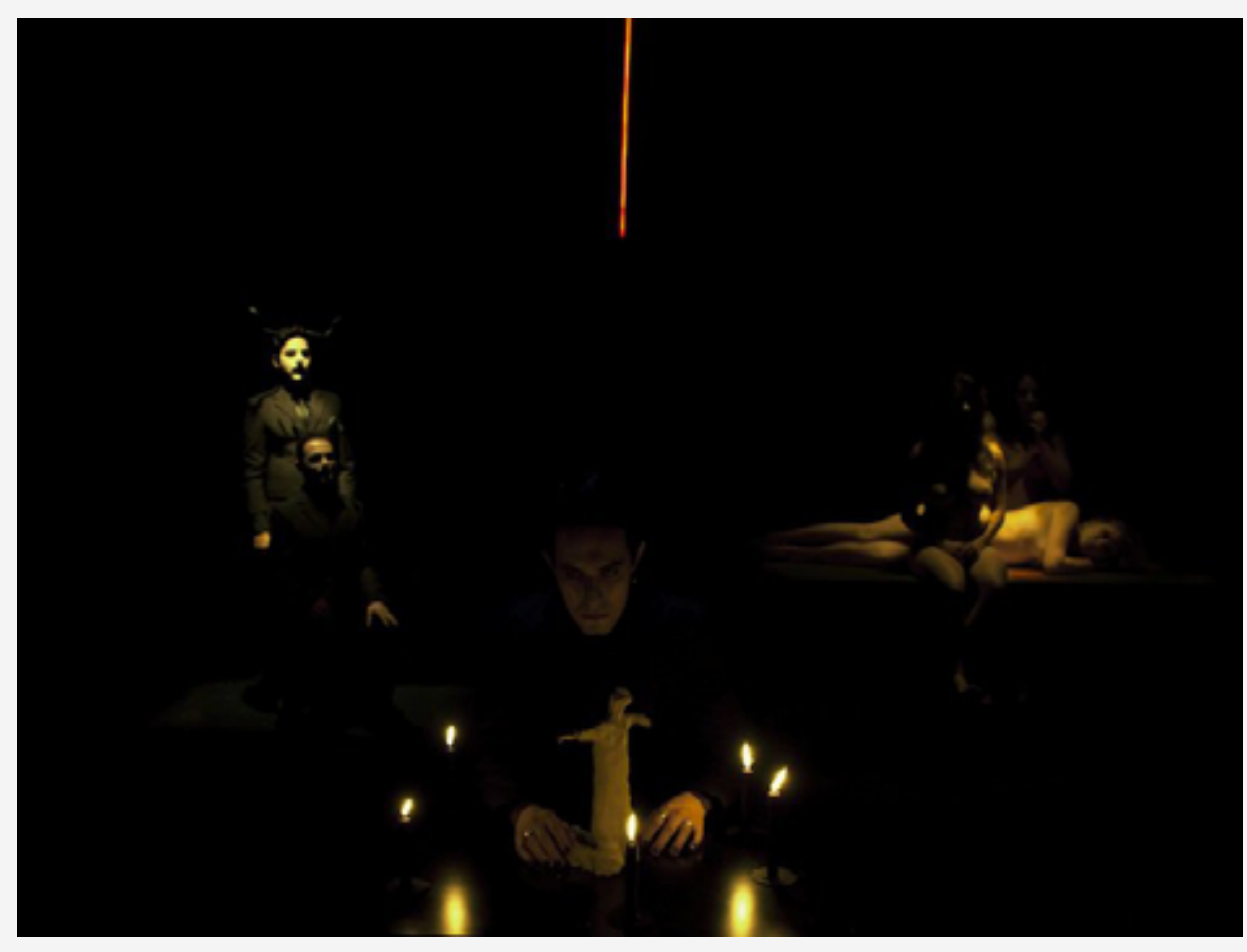

indicações de luz produzirão o efeito lusco-fusco visto na Figura 2. Dessa forma, podemos concluir que Alvim é coerente com suas proposições teóricas em diferentes níveis e categorias de seu processo criativo, não apenas em seu texto espetacular. Fato que corrobora esta hipótese é a visualidade de sua própria obra teórica, da qual apresentamos alguns trechos a seguir.

\section{A PRODUÇÃO TEATRAL}

Conforme assinala Rojo, a crítica deve tentar avançar "essa zona pouco definida entre o ver e o produzir". ${ }^{22}$ De acordo com a autora "as formas de produzir determinam as formas de visibilidade, e, portanto, também as percepções do mundo que transmite e que recepciona um determinado objeto poético-teatral". ${ }^{23}$ Isso significa dizer que os conceitos empregados durante cada etapa do fazer artístico envolvem uma concepção de teatro e uma micropolítica de criação e, finalmente, a imagem que chegará ao público será fruto de toda essa rede processual.

Segundo Didi-Huberman, “o que vemos só vale - só vive - em nossos olhos pelo que nos olha”. O conceito de dialética está por trás da ideia de que a imagem, ao ser olhada, obriga-nos a nos olharmos, e isso é o que a constitui e nos constitui em determinado momento. Por certo, essa operação também é de caráter temporal. $\mathrm{O}$ ato de olhar se configura, assim, no
22. ROJO. Teatro latino-americano em diálogo: produção e visibilidade, p. 36 .

23. ROJO. Teatro latino-americano em diálogo: produção e visibilidade, diálogo:

\section{Crítica Literária, outras Artes e Mídias}




\section{GENESIS}

por Roberto Alvim - 2015

(a Velha está sentada, a Criança está em seu colo; Deus está de pé)

VELHA.

a palavra

e a palavra

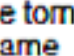

DEUS.

aqui:

VELHA.

a escuridão cobre os abismos

as palavras - voando sobre as águas

DEUS.

agora:

VELHA.
luz e treva agor

DEUS.

plantas / árvores / sementes

VELHA.

DEUS.

peixes nas águas pássaros no céu

com alegria com amor o precente / ecte filho oferece eete meu precente aqui

(sussurrando)

(tempo imóvel.

Hormerm se encurnint a Abel, púra diante déle e colocca a mũo direilu em sua cabeça. Aluz, entâo, llumina apenas o rosto de Caim)

CAlm.
(sussurrando)
por que?

(a luz abre também no rosto da Mulher, que fala para Caim)

MULHER.

por que?

esta noite escura em seu rosto tanta escuridão em seus olhos

CAIM.

que cotou sontindo agora / isto om mim:

nome do que sinto que me corrói dentro aqui

qual é o nome?

MULHER.

não sei / mas você

pode e se fala

diga o nome do que está dentro em vocé

etomará também vocé se tomarả tanló

um pai

(Caim se levanta:
a luz abre em Abel,

manece ajoelhado, sozinho

CAIM.

comesta palavra

tăo pequeno quanto 0

tao grande quanto ele

ois da minha boca agora nates antes por nenhum outsol 


\section{a intecpretes so certa?, the perguntaram. todas das, respondeu}

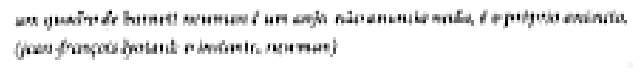

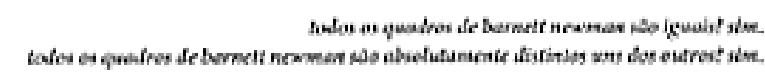

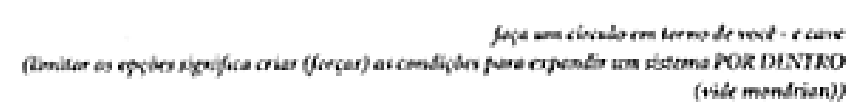

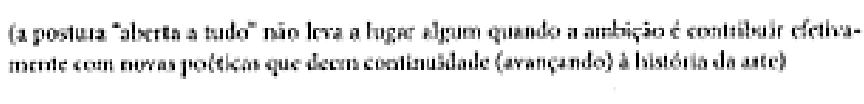

em uma obra de arte

tão importante quanto o que se faz é aquilo que 0 artista se RECUSA a fazer

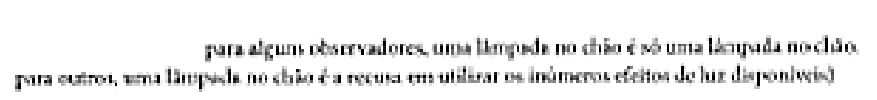

a história da arte nào e um peso que nos soletra (atitule

pos-moderna), mas uma montanhas en cima da qual nas nos

poicionamos

UMA TECNICA É UMA VISAO DE MUNDO

marar mochad

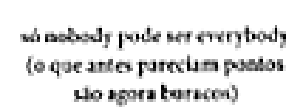

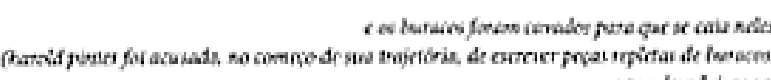

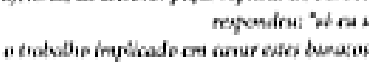

-.. sempretc armados

da bekera mis lancinante que pudermios

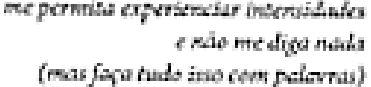


FIGURA 4 (B) - Montagem feita a partir de fotocópias das páginas 13 , Transumano.
DRAMÁTICAS DO TRANSUMANO

$$
\text { [Apontamestos (-) }
$$

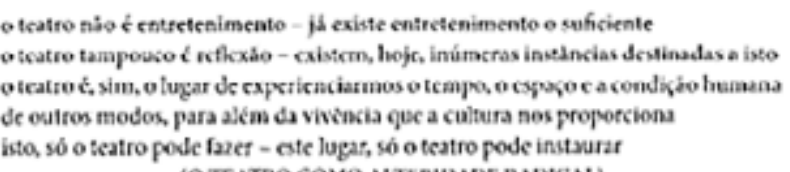

(OTEATRO COMO AITERIDADE RADCAL)

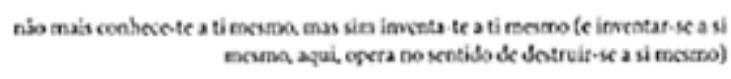

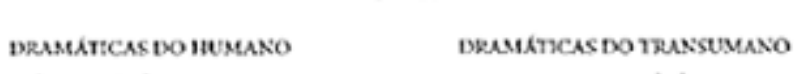

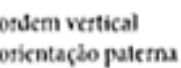

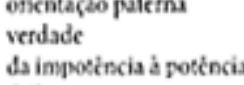

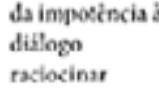

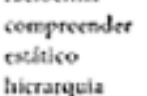

cedicratgei-
sentido

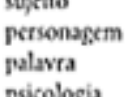

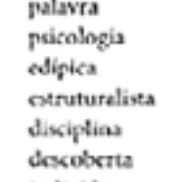

indiniduo

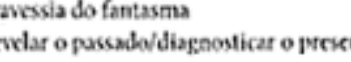
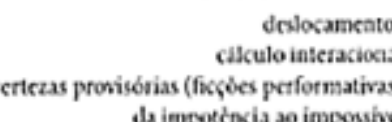

da impoctincia a impossice
mondogos atticlados

encarfimose

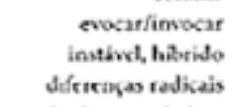



arguictetara linguidicas
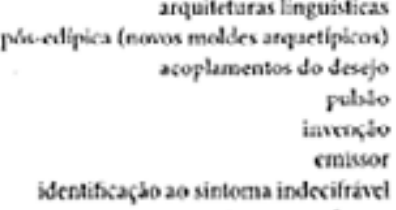

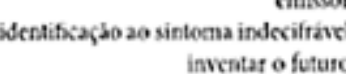

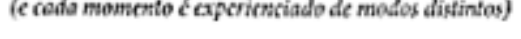

(1)

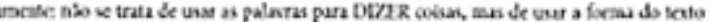



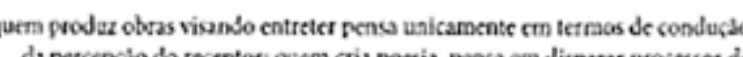

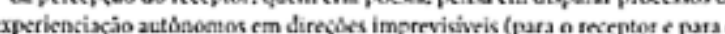

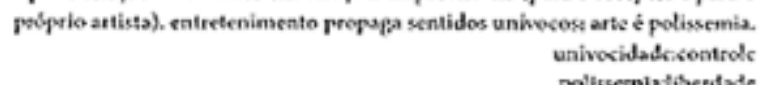

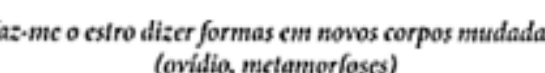

META

MORFO

LOGICUM

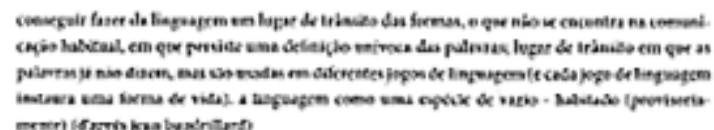

nsmutaça e metamorfose instauradas em ato radical ato

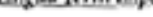

34 nós tinhamos o FATO;

depois, passamos a ter o forT e diversos

PONTOS DE VISTA distintos acercer

incia, o FATO desapareceu e só

os PONTOS DE VISTA

mais fatos

rabalhemos, pois, com este

estado-de-coisas

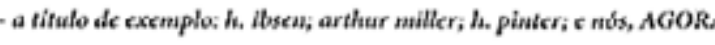

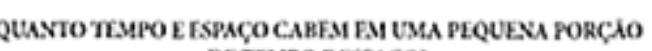

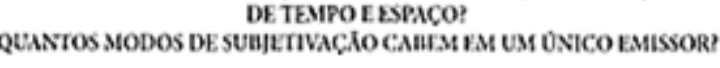



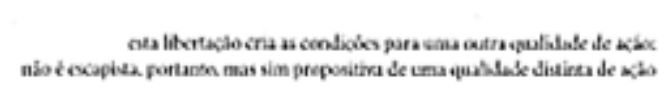

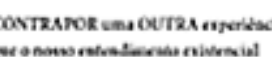

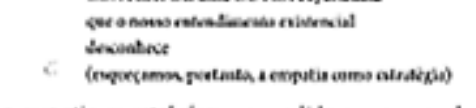

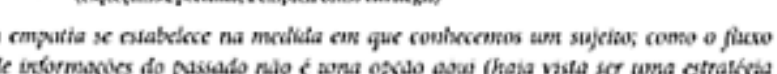

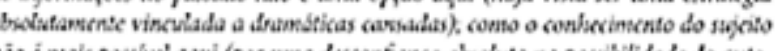

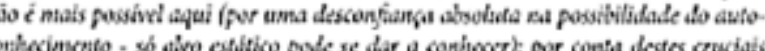

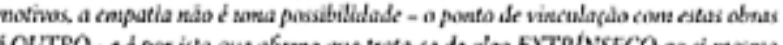


24. ROJO. Teatro latino-americano em diálogo: produção e visibilidade, p. 32

25. DIDI-HUBERMAN. Ante el tempo: história del arte y anacronismo de las imágenes, p. 11. Tradução nossa. tempo (passado e presente), que será, posteriormente, outros presentes, sendo cada um deles "uma experiência única" (Benjamin). Portanto, o espaço do olhar se constrói como um tempo único, mas, por sua vez, aberto a outros sucessivos e não determináveis a priori. ${ }^{24}$

Essa reflexão de Rojo nos permite adentrar ao conceito de anacronismo presente na obra de Didi-Huberman e buscar extrapolá-lo para uma imagem do espetáculo Tríptico Samue Beckett (2014), de Alvim.

O termo triptychos, em grego, significa "dobrado em três" e condensa bem a proposta de Alvim em distintos níveis primeiro, porque o espetáculo é baseado em três textos que o escritor Samuel Beckett publicou nos últimos anos de sua vida - Companhia (1980), Mal visto, mal dito (1981) e Pra frente o pior (1983) - e, segundo, porque as três atrizes em cena dão vida a mesma figura, representada em três momentos distintos da existência (infância, maturidade e velhice).

Para Didi-Huberman, as imagens são anacrônicas uma vez que, sendo portadoras de uma memória, acomodam "uma montagem de tempos heterogêneos e descontínuos que, no entanto, se conectam e se interpenetram ${ }^{25}$ ". Para o autor francês, estar diante de uma imagem é estar diante do tempo, pois, não importa o quão antiga ela seja, o presente nela não cessa de se reconfigurar - e vice-versa. O anacronismo seria a maneira temporal de exprimir toda a exuberância e sobredeterminação das imagens, ao passo que, na dialética (Benjamin) existente em seu interior, a concordância de tempos praticamente não existe.

Portanto, a imagem das três personagens criadas por Alvim na encenação de seu Tríptico não são senão a colisão de três temporalidades latentes em uma mesma vida. E o futuro que elas projetam é o fim desse próprio trajeto, conforme podemos ver na imagem do esqueleto prateado que permanece erguido no centro do palco durante toda a representação, bem atrás da personagem mais velha, interpretada pela atriz Nathália Timberg, de 86 anos.

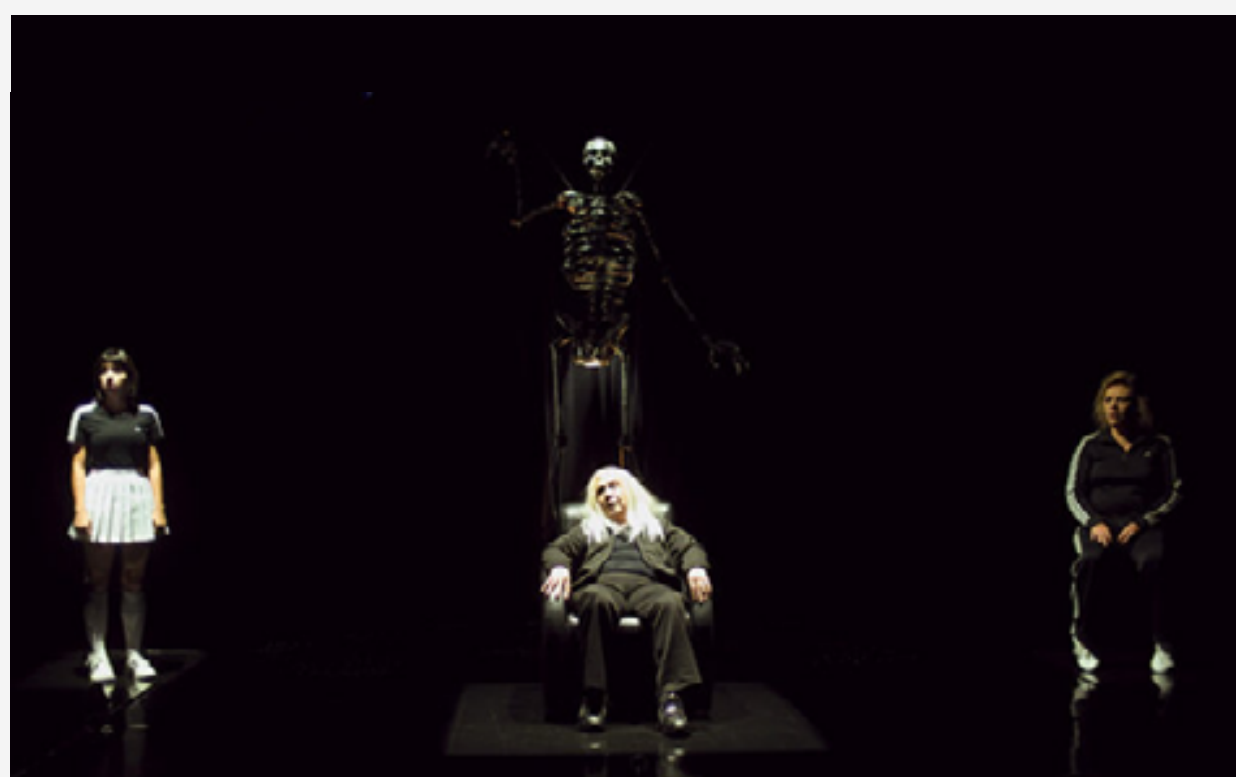

FIGURA 5 - Tríptico Samuel Beckett dramaturgia e direção de Roberto

\section{Crítica Literária, outras Artes e Mídias}


26. KANDINSKY apud KATTENBELT. $O$ teatro como arte do performer palco da intermidialidade, p. 117.

\section{CONSIDERAÇÕES FINAIS}

Buscamos com este trabalho realizar uma pequena exposição da obra de um artista ainda pouco estudado no campo da intermidialidade, mas que, no entanto, percebemos possuir no cerne de sua obra uma vasta potencialidade reflexiva. Fazemos coro a Kandinsky quando, falando sobre cores, sons e movimentos, assinalou que "o teatro tem um imã escondido, que tem o poder de atrair todas essas linguagens, todos os meios das artes, que juntos oferecem a maior possibilidade de arte abstrata monumental". ${ }^{26}$ Ora, se os gregos, que são considerados os criadores do teatro ocidental, utilizam a palavra graphein tanto significando "escrever" quanto "pintar", talvez resida justamente nesse primórdio o que Alvim realiza atualmente com seu teatro: uma escrita potencialmente pictural, portanto, imagética.

As imagens - as coisas visuais - são sempre lugares: elas aparecem como paradoxos em atos onde as coordenadas espaciais se ferem, abrem-se para nós e terminam por se abrir em nós, por nos abrir e em tudo isso nos incorporar. ${ }^{27}$

Percebemos nas imagens criadas por Alvim uma múltipla potência, ao passo que seu trabalho atende simultaneamente a ordens distintas (apesar de complementares) do saber, uma vez que teoria e prática sustentam dialeticamente sua criação artística. Quando o artista propõe que enxerguemos o teatro não como o espelho do mundo, mas sim como um palco possível para a invenção de outros mundos habitados por outras formas de vida, o que ele faz é tensionar o campo teatral na direção dos lugares heterotópicos dos quais Foucault nos fala. Assim, Alvim enriquece o teatro com suas arquiteturas linguísticas que ainda não haviam entrado em cena e, de fato, nossa concepção hegemônica do que venha a ser o sujeito - e, por conseguinte, o fazer teatral - é colocada em xeque.

Já na epígrafe deste trabalho, quando citamos um trecho da carta de Mallarmé a Verlaine, colocamos a questão de que a época contemporânea costuma ser sempre um interregno para o poeta, uma vez que ela é caduca e o trabalho do artista sempre tem vistas a mais tarde ou a jamais. Em diferentes momentos de sua carreira, Alvim foi reprovado por profissionais do teatro. Barbara Heliodora escreveu incontáveis críticas em sua coluna que desfavoreciam o trabalho do diretor. Como sabemos, uma crítica negativa é capaz de afastar o público do objeto criticado. Antunes Filho, na primeira vez em que assistiu o trabalho de Alvim, segundo o relato do próprio diretor, saiu da sala aos berros, dizendo que o que tinha acabado de ver não era teatro. Outra situação recorrente na classe teatral são as afirmações de que Alvim habita uma "torre de marfim", sendo um "elitista, burguês e alienado", e que muitas de suas obras não têm um caráter




28. Texto publicado por Roberto Alvim em sua pagina do Facebook. Disponivel em: <https://www. facebook.com/roberto.alvim.9> Acesso em 04/jul./2016. ostensivamente político - o que seriam uma crítica contundente para essas pessoas. Sobre esses temas, Alvim retalia:

\section{ora, sempre vi meu trabalho}

como sendo profundamente político

mesmo quando não falava sobre nosso país,

porque considero que

fazer um teatro sem nenhuma concessão ao senso-comum

ou a formas e discursos hegemônicos

e que se coloca aberto às pessoas

gratuitamente ou a preços módicos

visando garantir a maior acessibilidade possível

é um ato radicalmente político

- atuar sobre a sensibilidade e a inteligência do outro

(seja montando tragédias gregas, autores contemporâneos,

Beckett ou Shakespeare)

vale mais que qualquer discurso panfletário

porque EMANCIPA o indivíduo

ampliando sua capacidade crítica

para que ele faça suas próprias escolhas. ${ }^{28}$

Mediante tais especulações, encontramos na obra de Alvim imagens que borram as fronteiras entre letra, pintura, dramaturgia, encenação e teoria, deixando a cargo de quem acessa sua arte a possibilidade de ver imagens em sua mais ampla dinâmica.

\section{REFERÊNCIAS}

AGAMBEN, Giorgio. Aby Warburg e a ciência sem nome. In: BARTHOLOMEU, Cezar (Org.). Dossiê Warburg. Arte \& Ensaios n. 19. Rio de Janeiro: PPGAV/ Escola de Belas Artes, UFRJ, Dezembro de 2009, p. 118-143.

ANDRADE, Welington. Memento mori. São Paulo: Revista Cult Disponível em: <http://revistacult.uol.com.br/home/2014/02/ memento-mori/> . Acesso em: 02/jul./2016.

ARBEX, Márcia; BARBOSA, Márcio Venício; CASA NOVA, Vera (Org.). Interartes. Belo Horizonte: Editora UFMG, 2010.

ARBEX, Márcia (Org.). Poéticas do visível: ensaios sobre a escrita e a imagem. Belo Horizonte: Programa de Pós-Graduação em Letras: Estudos Literários, Faculdade de Letras da UFMG, 2006.

ALVIM, Roberto. A ambição da originalidade. Belo Horizonte: Horizonte da Cena, Entrevista concedida a Luciana Romagnolli e Soraia Belusi, 05 abr. 2013. Disponível em: < http://www. horizontedacena.com/a-ambicao-da-originalidade-entrevista-comroberto-alvim-2/>. Acesso em 30/jun./2016.

ALVIM, Roberto. Dramáticas do transumano e outros escritos seguidos de Pinokio. Rio de Janeiro: 7Letras, 2012.

BARTHES, Roland. Mitologias. Trad. Rita Buorgemino, Pedro de Souza e Rejane Janowitzer. $4^{\text {a }}$ ed. Rio de Janeiro: DIFEL, 2009.

BUTOR, Michel. Sobre a escrita e a arte. Trad. Márcia Arbex e Lívia Cristina Lopes Chaves. Belo Horizonte: viva voz, FALE/ UFMG, 2011. 
CHRISTIN, Anne-Marie. A imagem enformada pela escrita. In: ARBEX, Márcia (Org.). Poéticas do visível: ensaios sobre a escrita e a imagem. Belo Horizonte: Programa de Pós-Graduação em Letras: Estudos Literários, Faculdade de Letras da UFMG, 2006

DE MARINIS, Marco. Comprender el teatro. Lineamentos de una nueva teatrología. Trad. Cecilia Prenz. Buenos Aires: Galerna, 1997.

DIDI-HUBERMAN, Georges. Ante el tempo: história del arte y anacronismo de las imágenes. Trad. Antonio Oviedo. Buenos Aires: Adriana Hidalgo editora, 2011a.

DIDI-HUBERMAN, Georges. O que vemos, o que nos olha. Trad. Paulo Neves. São Paulo: Editora 34, 2010.

DIDI-HUBERMAN, Georges. Sobrevivência dos vaga-lumes Trad. Vera Casa Nova e Márcia Arbex. Belo Horizonte: Editora UFMG, 2011b.

KATTENBELT, Chiel. O teatro como arte do performer e palco da intermidialidade. In: DINIZ, Thais Flores Nogueira; VIEIRA, André Soares (Orgs). Intermidialidade e estudos interartes: desafios da arte contemporânea - Volume 2. Belo Horizonte: Rona Editora: FALE/UFMG, 2012

LOUVEL, Liliane. Nuanças do pictural. Trad. Márcia Arbex. In: DINIZ, Thais Flores Nogueira. Intermidialidade e estudos interartes: desafios da arte contemporânea. Belo Horizonte: Editora UFMG, 2012.

PAVIS, Patrice. Análise dos espetáculos. Trad. Sérgio Sálvia Coelho. São Paulo: Perspectiva, 2008.
PERRONE-MOISÉS, Leyla. Inútil poesia e outros ensaios breves. São Paulo: Companhia das Letras, 2000.

RAJEWSKY, Irina O. Intermidialidade, intertextualidade e

"remediação": uma perspectiva literária sobre a intermidialidade. Trad. Thais Flores Nogueira Diniz e Eliana Lourenço de Lima Reis. In: DINIZ, Thais Flores Nogueira. Intermidialidade e estudos interartes: desafios da arte contemporânea. Belo Horizonte: Editora UFMG, 2012.

ROJO, Sara. Teatro latino-americano em diálogo: produção e visibilidade. Belo Horizonte: Javali, 2016.

SEDLMAYER, Sabrina. Devolver ao uso comum: sobre a profanação da imagem em Giorgio Agamben e Lars Von Trier. In: ARBEX, Márcia; BARBOSA, Márcio Venício; CASA NOVA, Vera (Orgs). Interartes. Belo Horizonte: Editora UFMG, 2010.

\section{ESPETÁCULOS}

CLUB NOIR. Genesis, dramaturgia de Roberto Alvim e direção de Juliana Galdino, 2015

CLUB NOIR. Pinokio, dramaturgia e direção Roberto Alvim, 2011.

CLUB NOIR. Tríptico Samuel Beckett, dramaturgia e direção Roberto Alvim, 2014 